\title{
REFLECTIONS ON THE NATURE OF INDIVIDUALITY IN THE PROCESS OF IDENTIFYING HANDWRITING AND SIGNATURES
}

\author{
Janusz DZIECHCIARUK \\ Expert witness for the comparative investigation of handwriting and signatures on the Wrocław Regional Court List, \\ Poland
}

\begin{abstract}
The fundamental principle of identification, based on the condition that there is a unique combination of independent discriminating elements in handwriting, is analysed. The results of experiments conducted on distorted handwriting suggest that there may only be one handwriting habit that is responsible for the individuality of handwriting. By analysing disguised and simulated signatures and applying the isochrony principle, it seems reasonable to conclude that the mutual interaction between the speed of writing and the curvature of a graphic line is the only habit, and the quality of a graphic line the only feature responsible for the individuality of handwriting. The article introduces a number of ideas for evaluating the quality of a graphic line during handwriting examination, and a number of new opportunities for research into biometric electronic signatures.
\end{abstract}

\section{Keywords}

Habituation; Individuality; The isochrony principle; Line quality; Electronic signature.

Received 18 August 2021; accepted 6 October 2021

\section{Introduction}

The identification of handwriting is based on two commonly accepted assumptions (premises). The first is habituation, that is, being accustomed or inclined to perform particular actions more efficiently, more quickly, and more mechanically. Writing habits are neither instinctive (reflex) nor hereditary. Instead they are acquired in the course of the gradual development of extremely complicated perceptual-motor abilities (Harralson, Miller, 2018).

The second assumption underlying the identification of writing is its individuality, that is, its distinctiveness. The comparative handwriting research carried out by experts in this field is based precisely on the above assumptions: that the handwriting that takes its permanent shape from the habit of repeated activities is individual to each person and as such can be identified. At the same time, it is believed that the individuality of handwriting is defined by a combination of characteristic features unique to each person - each a manifestation (sign) of a particular writing habit (Kelly, Lindblom, 2006; Harralson, Miller, 2018).

In essence, the process of identifying handwriting involves comparing its formal graphical features, which are identified by comparing manuscripts, and assessing the correspondences and differences in terms of their origin, interdependence, or frequency of appearance. Consequently, it is accepted as a principle of handwriting identification that if two compared manuscripts contain a combination of independent distinguishing characteristics that are mutually consistent and occur in such number and significance (with such weight of identification) as to exclude the possibility of pure coincidence, and there are no inexplicable disparities, then it can be concluded that these 
manuscripts are the same in kind or were produced by a common source (Harralson, Miller, 2018).

It is clear that the above principle places emphasis on the necessity to distinguish the independent features of compared manuscripts. These are the features that do not exert a mutual influence or, in other words, that do not affect each other in any way. It would appear, however, that this capacity to isolate independent features in handwriting is contradicted by one of the principles formulated by Roy Huber and Alfred Headrick, which refers to distorted writing, and states that however such distortion is caused, it influences all of the writing's elements. This principle has been confirmed by numerous observations and experimental studies of disguised and forged handwriting that was set down under the influence of age, stress, alcohol overdoses, various diseases, and other internal and external factors (Fabiańska, Kubiś-Walasek, 2002; Napieralska-Ozga, 2002; Widła, 2002; Cheng, 2007; Equey, Marquis, Mazzella, 2007).

For example, if we take a closer look at the results of the experimental research into disguised script, the way in which controlled changes to certain graphic elements (the angle of slant of the script, the speed of the writing, and the types of graphic characters) significantly affect other properties of handwriting becomes clear. Changing the slant of handwriting causes a change not only in its general image, but also in the size of the script, including in the relative proportions of the individual letters, in the construction of the graphic characters, in the structure of the inter-letter links, in habits concerning the distribution of the speed and pressure of the writing tool on the surface, and in the rhythm of handwriting (Olejniczak, 2001; Morris, 2021). In turn, changes in the speed of writing have a significant impact on the shape and detail of individual graphic characters, on the handwriting's angle of slant, on the position of diacritics, on the structure of inter-letter links, on the impulse movements of the script, and on the proportions of the graphic elements (Galas, Widła, 2002; Podgajny, 2003). By contrast, changes in the type or size of handwriting to which the writer is not accustomed affect the fluency and speed of writing, which also manifests itself in unexpected and imprecise graphic movements and a tendency to simplify letter structures (Stachiewicz, 2001; Simsons, Spencer, Auer, 2011). As Ron Morris has stated, none of the characteristic features of handwriting can be altered without exerting an influence on its other characteristic features. If a writer interferes with any of their writing habits (of which the characteristic features of the writing are a visible sign), the writing as a whole is affected causing it to become generally distorted (Morris, 2021).

Therefore, since a change brought about within any one characteristic of the handwriting has a simultaneous effect on all the other characteristics, it is difficult to assert the existence of any independence of characteristics. If, as mentioned earlier, each characteristic is, as it were, a sign of a particular writing habit, then according to the results of the experimental research presented above, a change in any handwriting habit should induce simultaneous changes in all other handwriting habits. It would appear that the only logical explanation for this behaviour of the various graphic properties of handwriting is to accept the assumption that there exists a single handwriting habit, which in fact generates the individuality of handwriting.

The aim of this article is to attempt to define the individuality of handwriting through a detailed analysis of the results of experimental studies and observations of distorted handwriting and by reference to recent developments in the field of the motor control of handwriting. As it seems, only a complete understanding of the nature of individuality can guarantee the correct - and thus effective - implementation of the various stages of the handwriting- and signature-identification process.

\section{The individuality of handwriting as the result of the interaction between its speed and curvature}

Looking again at the results of the experimental research into disguised handwriting cited in the introduction, an interesting relationship can be observed: changes in the rate of writing, induced in a controlled manner, have a significant effect on the shape and details of individual graphic characters, as well as on inter-letter links and, conversely, changes in the slant and type of writing (i.e., involving a change in the shapes of individual graphic lines) induce changes in the speed of writing. It can therefore be supposed that there exists in writing that is set down naturally (undistorted) a type of mutual correlation between the speed of writing and the shape (curvature) of graphic lines. When the naturalness of writing is disturbed, for example by attempts to disguise writing, during which there is deliberate interference with the speed or shape (curvature) of a graphic line, this correlation is disrupted, which causes visible changes in all of the graphic elements of writing. The correlation described above can therefore constitute the single habit that generates individuality in handwriting. 
Attempts to forge signatures by the simulation method represent another interesting opportunity to observe the significant link between speed and curvature and the generation of individuality in handwriting. During this process, the primary objective of the forger is, of course, to perform their work in such a way that the forged signature resembles the genuine signature as closely as possible. To achieve this objective with one-hundred-per-cent efficiency, the forger would have to change the individuality of their own handwriting into that of the person whose signature is being forged. Analysis of this type of forgery in the subject literature very often points out that the forger is faced with a difficult dilemma: to faithfully reproduce the image (shape) of the forged signature, sacrificing the speed of writing somewhat, or to attempt to produce the signature at the most natural, smooth pace but reproduce the shapes of some elements of the forged signature inaccurately (Kelly, Lindblom, 2006). It can therefore be seen that knowledge of the characteristic correlation between the speed and curvature of writing occurring on the graphic lines of the forged signature is the key to resolving this difficulty.

However, even if we were to imagine (theoretically) that the forger had complete knowledge of this correlation, it would not offer them much assistance because the only way to write a forged signature with this (correct) correlation is to do so automatically (naturally, freely) by bypassing the conscious mind, which is absolutely impossible, since the process of forging a signature is a conscious act. Hence any attempt by a forger to accelerate the writing when forging a signature can only lead to them beginning to write in a way that is natural to them, in which case they expose themselves to identification by an expert.

It would appear, however, that the interaction between the speed and curvature of the graphic line of handwriting, and especially its importance as a factor generating its individuality, is best described by the principle of isochronism, which is one of the models of the motor control of handwriting. According to it, the rate at which writing is set down increases with the extent of the stroke (when the curvature along the line decreases), so that both the longer graphic line and the shorter, more curved line are written at approximately the same time. Consequently, the time taken to produce, e.g. two signatures of different sizes, is approximately constant (Caligiuri, Mohammed, 2012). Thus, based on the above principle, which applies to handwriting and to naturally-produced signatures, the interaction between the speed and curvature of writing can be expressed as follows (Dziechciaruk, 2019):

$$
\mathrm{v} \times \mathrm{C} \approx \text { const }
$$

where $\mathrm{v}$ and $\mathrm{C}$ denote respectively: the speed of writing and the value of the curvature at any point on a graphic line. Since the graphic line in handwriting that is freely and naturally set down is characterized by stability, the product $\mathrm{v} \times \mathrm{C}$ in formula (1) is defined as the quality level, $\mathrm{Q}$, of the graphic line, which is a measure of the fluency (smoothness) of the writing resulting from the interaction of the speed and curvature of the writing along the entire length of the graphic line (Dziechciaruk, 2019):

$$
\mathrm{Q}=\mathrm{v} \times \mathrm{C}
$$

where Q - quality level of the graphic line, $\mathrm{v}$ - speed of setting down the writing, $\mathrm{C}$ - curvature of the graphic line.

It follows from equations (1) and (2) above that the level of quality of a graphic line, which is a measure of the interaction between the speed and curvature of writing, is approximately constant for the naturally-inscribed writing of all people. If, at the same time, we take into account (in accordance with the fundamental assumption on which the identification of handwriting is based) that handwriting is individual (distinct) for all people, and the interaction between the speed and curvature of handwriting is the only habit that creates its individuality (as demonstrated by the results of experimental studies on distorted handwriting discussed above), it may be concluded that the quality of a graphic line is a characteristic that fully determines the individuality of handwriting.

\section{Discussion and concluding remarks}

It is worth noting that the concept of the individuality of handwriting set out here, which therefore also concerns the identification of handwriting and signatures, is consistent with the views of a number of other researchers who have addressed this issue. According to Stevan Slyter, for example, the simultaneous analysis of the rhythm of writing, which he understands as the aspect of writing responsible for its dynamics, and the form (shape) of writing plays a key role in identifying handwriting and signatures (Slyter, 1995). In the view of Roy Huber and Alfred Headrick, meanwhile, two properties are important in assessing the identification value of the distinctive elements of writing: its fluency (understood here as a factor responsible for the dynamics of writing, and thus obviously concerned with its speed) and the complexity of its graphic lines, in other words, the changing character of their 
curvature. Huber and Headrick also state that analysis of the above two properties should take place simultaneously if the material is to be evaluated to best effect (Harralson, Miller, 2018).

Although the scholars mentioned above place particular emphasis on the importance of simultaneous analysis of speed and curvature in handwriting identification, it seems clear that the key factor in this process is the interaction of these two fundamental properties of handwriting, which is at the same time responsible for generating its individuality. Expert witnesses who conduct comparative examinations of handwriting (signatures) simultaneously analyse the speed of writing (usually assessed based on the way in which the graphic lines are shaded, the distribution of the covering material on the surface, the pressure of the writing tool, and the presence of angular elements or a tremor in the writing) and the curvature of the writing, which in essence means that they analyse the level of quality of the graphic line as a measure of the interaction between the speed of writing and its curvature. This analysis usually boils down to assessing the degree of regularity (fluidity) of individual graphic lines or the rhythm of the writing, which is usually defined as the harmonious repetition of pressure, impulse movements, and graphic movements (Harralson, Miller, 2018), or as regularity in the curvature of writing (Kelly, Lindblom, 2006).

This means of analysing the level of quality of the graphic line is, of course, very general due to the impossibility of making precise measurements of the constantly changing writing speed and curvature along individual graphic lines. Moreover, the interaction between the speed of writing and the curvature only occurs when writing is in progress, whereas expert witnesses analyse what is known as 'static' handwriting, which represents the traces (residues) visible on the surface that result from an act of writing that is already in the past. Thus, despite the fact that the level of quality of a graphic line (as resulting from the considerations set out above) is a characteristic that fully determines the individuality of handwriting, the methods available to measure the speed of writing and curvature of graphic lines make it difficult to imagine how an effective, conclusive comparative analysis of the level of quality of graphic lines in compared manuscripts (signatures) could be conducted.

However, even a highly general analysis of the level of quality of a graphic line is extremely important for handwriting identification, as it makes it possible to assess all of the material under investigation in terms of how far it has been written naturally and to precisely separate fragments of handwriting that have been distorted. This provides a basis for compiling sets of comparisons of the graphical elements (properties) identified in the material analysed (which were drawn in a natural way, i.e., at a stable level of the quality of the graphical line) and, as a result, for drawing reliable, binding conclusions as to the uniformity or non-uniformity of the handwriting under examination.

To sum up the above considerations and remarks: the concept presented does not appear to be inconsistent with the actual practice of handwriting identification and signature identification (in accordance with the classical understanding of the nature of the individuality of handwriting). Indeed, it may even enable a deeper understanding of the nature and purpose of its various stages. This understanding assumes particular importance when examining handwriting that is in any way distorted. If so, continual assessment of the interaction between the speed of writing and the curvature along all of the graphic lines of the examined handwriting (signatures) is a fundamental condition for carrying out reliable comparative studies.

When investigating the definition of the level of quality of a graphic line (equation 2), it is worth asking whether it is possible to mathematically measure the characteristic that fully defines the individuality of handwriting and signatures. A qualitative assessment of the level of quality of a graphic line could clearly be extremely beneficial when used, for example, in the examination of electronic biometric signatures. Current methods are based on an analysis of the dynamic properties of signatures, that is, primarily on the speed of writing and on the acceleration, pressure, or frequency of detachment of the writing instrument from the surface (Harralson, 2013). Yet these methods suffer from an important limitation: they cannot precisely track (along individual graphic lines) the naturalness with which signatures are set down, and so cannot distinguish between naturally drafted and distorted fragments, which is very important, for example, when examining disguised signatures.

The only way to conduct a reliable and precise evaluation of the naturalness of handwriting and signatures, and thus to determine where they have been distorted, is to simultaneously analyse the speed and curvature of the handwriting, which means, in essence, to assess the level of quality of its graphic line. It is possible that this problem (the quantitative analysis of the level of quality of a graphic line) can be solved in practice by constructing the function $\mathrm{Q}(\mathrm{t})=$ $\mathrm{v} \times \mathrm{C}(\mathrm{t})$ (Dziechciaruk, 2019). This function would make it possible to analyse the value of the product $\mathrm{v} \times \mathrm{C}$ (during the writing of the graphic line under examination) measured at successive points along 
this line, which correspond to successive moments in time. Since the level of quality of a graphic line fully determines the individuality of handwriting, the $\mathrm{Q}(\mathrm{t})$ function above can also be employed as an attempt at a complete mathematical description of the individuality of handwriting and signatures.

An in-depth understanding of the nature of the individuality of handwriting will undoubtedly be important in achieving even more reliable and accurate opinions in studies designed to identify handwriting and signatures. It can also greatly assist in developing more effective and precise computer methods for compiling expert opinions of handwriting, which would be based on the comprehensive and simultaneous analysis of the two fundamental properties whose interaction creates the individuality of handwriting: its speed, which is responsible for its dynamics, and its curvature, which is responsible for its shape.

\section{References}

1. Caligiuri, M. P., Mohammed, L. A. (2012). The neuroscience of handwriting. Boca Raton: CRC Press.

2. Cheng, Y.-S. P. (2007). A study on the influence of wearing a glove on handwriting by Chinese in Hong Kong. Journal of the American Society of Questioned Documents Examiners, 10(1), 29-41.

3. Dziechciaruk, J. (2019). The significance of curvature in identification analyses of handwriting and signatures. Problems of Forensic Sciences, 120, 301-311.

4. Equey, C., Marquis, R., Mazzella, W. D. (2007). Influence of writing posture on the dimensions of signatures. Journal of the American Society of Questioned Documents Examiners, 10(2), 53-59.

5. Fabiańska, E., Kubiś-Walasek, B. (2002). Badania nad zmiennością pisma ręcznego osób starszych. (In) Z. Kegel (Ed.), Problematyka dowodu z ekspertyzy dokumentów (pp. 1275-1279). Wrocław: Uniwersytet Wrocławski.

6. Galas, K., Widła, T. (2002). Zmiany w piśmie spowodowane radykalnym spowolnieniem kreślenia. (In) Z. Kegel (Ed.), Problematyka dowodu z ekspertyzy dokumentów (pp. 408-411). Wrocław: Uniwersytet Wrocławski.

7. Harralson, H. H. (2013). Developments in handwriting and signature identification in the digital age. Amsterdam: Anderson Publishing.

8. Harralson, H. H., Miller, L. S. (2018). Huber and Headrick's handwriting identification: Facts and fundamentals. Boca Raton: CRC Press.

9. Kelly, J. S., Lindblom, B. S. (2006). Scientific examination of questioned documents. $2^{\text {nd }}$ edition. Boca Raton: CRC Press.
10. Morris, R. N. (2021). Forensic handwriting identification. Fundamental concepts and principles. Cambridge: Academic Press.

11. Napieralska-Ozga, E. (2002). Wybrane zagadnienia wpływu zmian ustroju psychofizycznego człowieka oraz innych czynników na wygląd pisma ręcznego, a w szczególności podpisów. (In) Z. Kegel (Ed.), Problematyka dowodu z ekspertyzy dokumentów (pp. 102-107). Wrocław: Uniwersytet Wrocławski.

12. Olejniczak, P. (2001). Możliwości identyfikacji wykonawcy pisma ręcznego w przypadku zmiany naturalnego kąta kreślenia. (In) W. Stachewicz, P. Olejniczak, J. Żelazko, W. Porcz, W. Rybczyńska, Zeszyt metodyczny $n r$ 11: Metody maskowania zapisów odręcznych (pp. 33-61). Warszawa: CLK KGP.

13. Podgajny, S. (2003). Wpływ tempa kreślenia i pozycji pisarskiej na obraz podpisów własnych. (In) K. WójtowiczGarcarz, S. Podgajny, J. Koszelak, Zeszyt metodyczny nr 18: Wplyw czynników wolicjonalnych i pozawolicjonalnych na obraz podpisu (pp. 31-56). Warszawa: CLK KGP.

14. Simsons, D., Spencer, R., Auer, S. (2011). The effects of constraining signatures. Journal of the American Society of Questioned Documents Examiners, 14(1), 39-50.

15. Slyter, S. A. (1995). Forensic signature examination. Springfield: Charles C. Thomas Publisher.

16. Stachewicz, W. (2001). Zmiana nawykowego obrazu pisma ręcznego jako wynik celowej deformacji graficznej. (In) W. Stachewicz, P. Olejniczak, J. Żelazko, W. Porcz, W. Rybczyńska, Zeszyt metodyczny nr 11: Metody maskowania zapisów odręcznych (pp. 63-85). Warszawa: CLK KGP.

17. Widła, T. (2002). Wpływ pozycji pisarskiej na grafizm. Problematyka dowodu z ekspertyzy dokumentów. (In) Z. Kegel (Ed.), Problematyka dowodu z ekspertyzy dokumentów (pp. 389-391). Wrocław: Uniwersytet Wrocławski.

\author{
Corresponding author \\ Janusz Dziechciaruk \\ ul. Gajowa 28/9 \\ PL 50-519 Wrocław \\ e-mail: j.dziechciaruk@vp.pl
}




\section{ROZWAŻANIA NAD ISTOTĄ INDYWIDUALNOŚCI I PROCESEM IDENTYFIKACJI PISMA RĘCZNEGO I PODPISÓW}

\section{Wprowadzenie}

Identyfikacja pisma ręcznego jest oparta na dwóch powszechnie przyjętych założeniach (przesłankach). Pierwszym z nich jest nawykowość (habituation), czyli przyzwyczajanie się, skłonność do sprawniejszego, szybszego, bardziej mechanicznego wykonywania określonych czynności. Nawyki pisarskie nie są ani instynktowne (odruchowe), ani dziedziczne; zostają one nabyte w drodze stopniowego rozwijania bardzo skomplikowanych percepcyjno-motorycznych umiejętności pisarskich (Harralson, Miller, 2018).

Drugim założeniem stanowiącym podstawę identyfikacji pisma jest jego indywidualność (individuality), czyli odrębność. Badania porównawcze pisma ręcznego, przeprowadzane przez ekspertów zajmujących się tą problematyką, bazują właśnie na powyższych założeniach, a więc, że pismo ukształtowane $\mathrm{w}$ wyniku nawykowo utrwalonych, wielokrotnie powtarzanych czynności jest indywidualne dla każdego człowieka i jako takie może być zidentyfikowane. Jednocześnie uważa się, że indywidualność pisma ręcznego określona jest przez unikalną dla każdego człowieka kombinację cech charakterystycznych, przy czym każda $\mathrm{z}$ tych cech jest przejawem (oznaką) określonego nawyku pisarskiego (Kelly, Lindblom, 2006; Harralson, Miller, 2018).

Proces identyfikacji pisma ręcznego $\mathrm{w}$ istocie sprowadza się do porównywania elementów wyróżniających, czyli cech charakterystycznych grafizmu, wyodrębnionych $\mathrm{w}$ zestawionych ze sobą rękopisach, a następnie oceny stwierdzonych $w$ ten sposób zgodności i różnic pod kątem ich pochodzenia, wzajemnej zależności bądź też częstotliwości pojawiania się. W konsekwencji jako zasadę identyfikacji pisma ręcznego przyjmuje się, że jeśli dwa zestawione rękopisy zawierają kombinację niezależnych elementów wyróżniających, które są wzajemnie zgodne i występują w takiej liczbie i znaczeniu (to jest wadze identyfikacyjnej), które wykluczają możliwość przypadkowej zbieżności, a jednocześnie brak jest fundamentalnych (niedających się wytłumaczyć) różnic, to można stwierdzić, że rękopisy te zostały sporządzone przez jedną osobę (Harralson, Miller, 2018).

Jak więc wyraźnie widać, $\mathrm{w}$ powyższej zasadzie kładzie się nacisk na konieczność wyodrębnienia w zestawionych ze sobą rękopisach cech niezależnych, czyli niewywierających wzajemnie na siebie wpływu, inaczej mówiąc - nieoddziałujących w żaden sposób na siebie. Wydaje się jednak, że takiej możliwości wyodrębnienia cech niezależnych w piśmie ręcznym przeczy jedna ze sformułowanych przez Hubera i Headricka zasad odnoszących się do pisma pogorszonego (zaburzonego), zgodnie z którą pogorszenie pisma spowodowane jakąkolwiek przyczyną wywiera wpływ na wszystkie jego elementy. Zasada ta została potwierdzona licznymi obserwacjami i badaniami eksperymentalnymi dotyczącymi pisma maskowanego i podrobionego, sporządzonego pod wpływem różnych chorób, wieku, stresu, w wyniku przedawkowania alkoholu i innych czynników wewnętrznych i zewnętrznych (Fabiańska, Kubiś-Walasek, 2002; Napieralska-Ozga, 2002; Widła, 2002; Cheng, 2007; Equey, Marquis, Mazzella, 2007).

I tak przykładowo - jeżeli przyjrzeć się bliżej wynikom badań eksperymentalnych nad pismem maskowanym, zwraca uwagę to, jak wywoływane w sposób kontrolowany zmiany niektórych elementów graficznych (kąta pochylenia pisma, tempa kreślenia, typu znaków graficznych) w sposób istotny wpływają na inne właściwości grafizmu. Zmiana pochylenia pisma wywołuje nie tylko zmianę jego ogólnego obrazu, ale również wielkości pisma (w tym wzajemnych proporcji pomiędzy poszczególnymi literami), konstrukcji znaków graficznych, budowy wiązań międzyliterowych, a także nawyków dotyczących rozkładu prędkości i nacisku narzędzia pisarskiego na podłoże oraz rytmu pisma (Olejniczak, 2001; Morris, 2021). Z kolei zmiany w tempie kreślenia mają znaczący wpływ na kształt i detale poszczególnych znaków graficznych, kąt pochylenia pisma, usytuowanie znaków diakrytycznych, budowę wiązań międzyliterowych, impuls pisma, a także proporcje elementów graficznych (Galas, Widła, 2002; Podgajny, 2003). Natomiast zmiany w typie lub wielkości pisma, do którego osoba pisząca nie jest przyzwyczajona, mają wpływ na biegłość i tempo kreślenia, co przejawia się również $\mathrm{w}$ nieoczekiwanych i nieprecyzyjnych ruchach graficznych oraz tendencji do uproszczenia konstrukcji liter (Stachewicz, 2001; Simsons, Spencer, Auer, 2011). Jak twierdzi Ron Morris, żadna $\mathrm{z}$ cech charakterystycznych pisma nie może być zmieniona bez wywołania wpływu na inne cechy charakterystyczne. Jeśli osoba pisząca dokonuje jakiejkolwiek ingerencji dotyczącej swoich nawyków pisarskich (których widoczną oznaką są cechy charakterystyczne pisma), wywiera to wpływ na całość pisma, powodując jego ogólne zaburzenie (Morris, 2021).

Skoro zatem zmiana wywołana w obrębie dowolnej cechy charakterystycznej pisma ma jednoczesny wpływ na wszystkie inne cechy, trudno jest tutaj mówić 
o jakiejkolwiek niezależności cech charakterystycznych. Ponieważ, jak już wcześniej wspomniano, każda cecha charakterystyczna jest niejako oznaką określonego nawyku pisarskiego, to zgodnie z przedstawionymi powyżej wynikami analiz badań doświadczalnych zmiana jakiegokolwiek nawyku pisarskiego powinna wywoływać jednoczesne zmiany wszystkich innych nawyków. Wydaje się, że jedynym logicznym wyjaśnieniem takiego zachowania poszczególnych właściwości graficznych pisma jest przyjęcie założenia o istnieniu jednego nawyku pisarskiego, który w istocie kreuje indywidualność pisma ręcznego.

Celem niniejszego artykułu jest próba określenia istoty indywidualności pisma ręcznego poprzez szczegółową analizę wyników badań doświadczalnych i obserwacji pisma zaburzonego, a także wykorzystanie najnowszych osiągnięć z dziedziny kontroli motorycznej pisma ręcznego. Jak się wydaje, tylko pełne zrozumienie istoty indywidualności może dać gwarancję prawidłowej, a tym samym skutecznej realizacji poszczególnych etapów procesu identyfikacji pisma ręcznego i podpisów.

\section{Indywidualność pisma ręcznego jako wynik wzajemnego oddziaływania tempa kreślenia i krzywizny pisma}

Przyglądając się ponownie przytoczonym we wprowadzeniu wynikom badań eksperymentalnych nad pismem maskowanym, można zauważyć interesującą zależność: wywoływane w sposób kontrolowany zmiany tempa kreślenia pisma miały znaczący wpływ na kształt i detale poszczególnych znaków graficznych, a także wiązania międzyliterowe, i odwrotnie - zmiany dotyczące pochylenia i typu pisma (czyli wiążące się ze zmianą kształtów poszczególnych linii graficznych) wywoływały zmiany tempa kreślenia. Można zatem przypuszczać, że w piśmie kreślonym w sposób naturalny (niezaburzony) istnieje rodzaj wzajemnej korelacji pomiędzy tempem kreślenia a kształtem (krzywizną) linii graficznych. W przypadku gdy dochodzi do zaburzenia naturalności kreślenia, na przykład próby maskowania pisma, podczas której w sposób świadomy dokonujemy ingerencji dotyczącej tempa bądź kształtu (krzywizny) linii graficznej, powyższa korelacja ulega zakłóceniu, wywołując zmiany obserwowane we wszystkich elementach graficznych pisma. Tak więc opisana powyżej korelacja może stanowić ten jedyny nawyk, który kreuje indywidualność pisma ręcznego.

Innym interesującym przykładem, na którym można zaobserwować istotny związek pomiędzy tempem kreślenia i krzywizną z kreowaniem indywidualności pisma ręcznego, jest próba podrabiania podpisu metodą naśladownictwa. W trakcie tego procesu zasadniczym celem fałszerza jest oczywiście dokonanie tej czynności w taki sposób, aby podrobiony podpis był zbliżony maksymalnie do podpisu autentycznego. Osiągnięcie tego celu ze stuprocentową skutecznością wiązałoby się więc ze zmianą indywidualności własnego grafizmu na indywidualność grafizmu osoby, której podpis jest podrabiany. W literaturze przedmiotu bardzo często w trakcie analizy tego rodzaju fałszerstw zwraca się uwagę na to, że fałszerz staje przed trudnym dylematem, czy wiernie oddać obraz (kształt) podrabianego podpisu, poświęcając przy tym nieco tempo kreślenia, czy też próbować sporządzić podpis $\mathrm{w}$ możliwie naturalnym, swobodnym tempie, ale jednocześnie niedokładnie odwzorować kształty niektórych elementów podrabianego podpisu (Kelly, Lindblom, 2006). Jak więc widać, kluczem do rozwiązania powyższego dylematu jest $\mathrm{w}$ istocie znajomość charakterystycznej korelacji pomiędzy tempem kreślenia a krzywizną, zachodzącej wzdłuż linii graficznych podrabianego podpisu.

Jednak nawet jeśliby wyobrazić sobie (teoretycznie), że fałszerz posiadł kompletną wiedzę odnośnie do tej korelacji, to można się przekonać, że niewiele by mu ona pomogła, ponieważ jedynym sposobem, aby nakreślić podrobiony podpis z tą (właściwą) korelacją, jest dokonanie tego w sposób automatyczny (naturalny, swobodny), a więc z wyłączeniem świadomości, co jest absolutnie niemożliwe, gdyż proces podrabiania podpisu jest czynnością świadomą. Tak więc wszelkie próby przyspieszania kreślenia podczas podrabiania podpisu przez fałszerza mogą jedynie doprowadzić do sytuacji, kiedy zacznie on kreślić w sposób dla niego naturalny, a wówczas naraża się na zidentyfikowanie przez eksperta.

Wydaje się jednak, że istotę wzajemnego oddziaływania pomiędzy tempem kreślenia a krzywizną linii graficznej pisma, a zwłaszcza jego znaczenie jako czynnika kreującego indywidualność pisma ręcznego, najpełniej określa zasada izochronizmu, stanowiąca jeden $\mathrm{z}$ modeli kontroli motorycznej pisma ręcznego. Zgodnie z tą zasadą tempo kreślenia pisma wzrasta wraz z zasięgiem ruchu graficznego (a więc kiedy krzywizna wzdłuż linii maleje), przez co zarówno dłuższa linia graficzna, jak i krótsza - bardziej zakrzywiona, kreślone są w przybliżeniu w tym samym czasie. W konsekwencji czas sporządzenia np. dwóch podpisów różniących się rozmiarami jest w przybliżeniu stały (Caligiuri, Mohammed, 2012). Tak więc, na podstawie powyższej zasady (która odnosi się do pisma ręcznego i podpisów sporządzonych w sposób naturalny), wzajemne oddziaływanie pomiędzy tempem kreślenia a krzywizną pisma można wyrazić w postaci następującej zależności (Dziechciaruk, 2019):

$$
\mathrm{v} \times \mathrm{C} \approx \text { const }
$$

gdzie v i C oznaczają odpowiednio: tempo kreślenia i wartość krzywizny w dowolnym punkcie linii graficznej. Ponieważ, jak wiadomo, kreślone w sposób swobodny i naturalny pismo ręczne charakteryzuje się stabilną 
jakością linii graficznej, iloczyn $\mathrm{v} \times \mathrm{C}$ we wzorze (1) został określony jako poziom jakości linii graficznej $\mathrm{Q}$, czyli miara biegłości (płynności) pisma będąca wynikiem oddziaływania tempa kreślenia i krzywizny pisma na całej długości linii graficznej (Dziechciaruk, 2019):

$$
\mathrm{Q}=\mathrm{v} \times \mathrm{C}
$$

gdzie Q - poziom jakości linii graficznej, $\mathrm{v}$ - tempo kreślenia pisma, $\mathrm{C}$ - krzywizna linii graficznej.

Z powyższych wzorów (1) i (2) wynika, że poziom jakości linii graficznej, stanowiący miarę wzajemnego oddziaływania pomiędzy tempem kreślenia i krzywizną, jest w przybliżeniu stały w odniesieniu do naturalnie kreślonego pisma każdej osoby. Jeśli więc jednocześnie uwzględnimy (zgodnie z fundamentalnym założeniem, na którym opiera się identyfikacja pisma ręcznego), że pismo jest indywidualne (odrębne) dla każdego człowie$\mathrm{ka}$, a wzajemne oddziaływanie pomiędzy tempem kreślenia i krzywizną jest jedynym nawykiem kreującym indywidualność pisma ręcznego (jak wykazują omówione powyżej wyniki badań doświadczalnych nad pismem zaburzonym), to daje to podstawę do wniosku, że poziom jakości linii graficznej jest cechą charakterystyczną w pełni określającą indywidualność pisma ręcznego.

\section{Dyskusja i uwagi końcowe}

Warto zauważyć, że zaprezentowana w tej pracy koncepcja indywidualności pisma ręcznego, a więc również dotycząca identyfikacji pisma ręcznego i podpisów, jest zbieżna z poglądami szeregu innych badaczy zajmujących się tą problematyką. I tak na przykład zgodnie z poglądem Stevana Slytera kluczową rolę w identyfikacji pisma ręcznego (podpisów) pełni jednoczesna analiza rytmu pisma (rozumianego przez tego badacza jako aspekt pisma odpowiadający za jego dynamikę) oraz formy (kształtu) pisma (Slyter, 1995). Z kolei według Hubera i Headricka istotne znaczenie przy ocenie wartości identyfikacyjnej elementów wyróżniających grafizmu mają dwie właściwości: biegłość pisma (rozumiana tutaj jako czynnik odpowiadający za dynamikę pisma, a więc w oczywisty sposób dotyczący tempa jego kreślenia) oraz stopień skomplikowania linii graficznych pisma, czyli innymi słowy zmieniający się charakter krzywizn tych linii. Jednocześnie, zgodnie $\mathrm{z}$ opinią tych badaczy, aby przeprowadzona ocena materiału była najbardziej skuteczna, analiza powyższych dwóch właściwości powinna odbywać się równocześnie (Harralson, Miller, 2018).

Wprawdzie wyszczególnieni powyżej badacze w wyrażanych przez siebie poglądach szczególnie akcentowali znaczenie jednoczesnej analizy tempa kreślenia i krzywizny w procesie identyfikacji pisma ręcznego, wydaje się jednak oczywiste, że kluczowy czynnik w tym procesie stanowi wzajemne oddziaływanie powyższych dwóch fundamentalnych właściwości grafizmu, które jest jednocześnie odpowiedzialne za kreowanie indywidualności pisma ręcznego. W trakcie przeprowadzania badań porównawczych pisma ręcznego (podpisów) ekspert specjalizujący się w tego rodzaju badaniach dokonuje jednoczesnej analizy tempa kreślenia (ocenianego najczęściej na podstawie sposobu cieniowania linii graficznych, rozłożenia środka kryjącego na podłożu, nacisku narzędzia pisarskiego bądź też obecności elementów kątowych lub tremoru $\mathrm{w}$ piśmie) oraz krzywizny pisma, a więc $\mathrm{w}$ istocie analizuje poziom jakości linii graficznej jako miarę wzajemnego oddziaływania tempa kreślenia i krzywizny. Analiza ta sprowadza się najczęściej do oceny stopnia regularności (płynności) poszczególnych linii graficznych bądź też rytmu pisma, definiowanego zazwyczaj jako harmonijne powtarzanie nacisku, impulsu i ruchów graficznych (Harralson, Miller, 2018), albo też regularność w krzywiźnie pisma (Kelly, Lindblom, 2006).

Przeprowadzona w ten sposób analiza poziomu jakości linii graficznej jest oczywiście bardzo ogólna z uwagi na brak możliwości dokonania precyzyjnych pomiarów zmieniającego się nieustannie tempa kreślenia i krzywizny wzdłuż poszczególnych linii graficznych. Jak wiadomo również, wzajemne oddziaływanie pomiędzy tempem kreślenia a krzywizną zachodzi jedynie w trakcie procesu kreślenia pisma, natomiast ekspert poddaje analizie tzw. pismo statyczne, czyli w istocie ślady (pozostałości) widniejące na podłożu, jako wynik sporządzonego w przeszłości aktu pisarskiego. Tak więc, pomimo że poziom jakości linii graficznej (jak wynika z przedstawionych w tej pracy rozważań) stanowi cechę charakterystyczną w pełni określającą indywidualność pisma ręcznego, przy obecnych możliwościach pomiarowych odnośnie do tempa kreślenia i krzywizny linii graficznej trudno sobie wyobrazić możliwość przeprowadzenia skutecznej, zakończonej wypracowaniem wiążących wniosków analizy porównawczej poziomów jakości linii graficznej zestawionych ze sobą rękopisów (podpisów).

Jednakże nawet analiza poziomu jakości linii graficznej o tak dużym stopniu ogólności jest niezwykle istotna dla całego procesu identyfikacji pisma ręcznego, pozwala bowiem na ocenę całości materiału badawczego pod kątem naturalności jego sporządzenia, a także na precyzyjne wyodrębnienie tych fragmentów grafizmu, które uległy zaburzeniu. Daje to podstawy do przeprowadzenia zestawień porównawczych wyodrębnionych w analizowanym materiale badawczym, elementów (właściwości) graficznych (które zostały nakreślone w sposób naturalny, a więc przy stabilnym poziomie jakości linii graficznej) i w rezultacie wypracowania wiarygodnych, wiążących wniosków w kwestii jednorodności lub niejednorodności badanego grafizmu.

Podsumowując zatem powyższe rozważania i uwagi: nie wydaje się, aby zaprezentowana tutaj koncepcja była sprzeczna $\mathrm{z}$ realizowanym $\mathrm{w}$ praktyce procesem 
identyfikacji pisma ręcznego i podpisów (zgodnie z klasycznym pojmowaniem natury indywidualności pisma ręcznego), może ona nawet umożliwiać głębsze zrozumienie istoty i celowości poszczególnych jego etapów. Zrozumienie to nabiera szczególnej wagi w przypadku badania pisma ręcznego w jakikolwiek sposób zaburzonego, wtedy bowiem fundamentalnym warunkiem przeprowadzenia $\mathrm{w}$ sposób wiarygodny badań porównawczych jest nieustannie prowadzona ocena wzajemnego oddziaływania pomiędzy tempem kreślenia a krzywizną wzdłuż wszystkich linii graficznych badanego pisma ręcznego (podpisów).

Analizując definicję poziomu jakości linii graficznej (wzór 2), warto zadać pytanie, czy istnieje możliwość matematycznej (pomiarowej) oceny tej charakterystycznej cechy, która w pełni określa indywidualność pisma ręcznego i podpisów. Wydaje się oczywiste, że taka ilościowa ocena poziomu jakości linii graficznej może być bardzo wartościowa, wykorzystana na przykład podczas badań elektronicznych podpisów biometrycznych. Stosowane tam obecnie metody opierają się zasadniczo na analizie właściwości dynamicznych podpisów, a więc przede wszystkim tempa kreślenia i przyspieszenia, nacisku bądź częstotliwości odrywania narzędzia pisarskiego od podłoża (Harralson, 2013). Metody te mają jednak istotne ograniczenie - nie są one w stanie w sposób precyzyjny śledzić (wzdłuż poszczególnych linii graficznych) stopnia naturalności kreślenia podpisu, a tym samym rozróżniać fragmentów sporządzonych w sposób naturalny od fragmentów zaburzonych, co jest bardzo istotne np. przy badaniu podpisów maskowanych.

Jedynym sposobem na przeprowadzenie wiarygodnej i precyzyjnej oceny naturalności kreślenia pisma ręcznego i podpisów, a tym samym ustalenia miejsc, w których grafizm uległ zaburzeniu, jest jednoczesna analiza tempa kreślenia i krzywizny pisma, czyli w istocie ocena poziomu jakości linii graficznej pisma. Wydaje się, że możliwym praktycznym rozwiązaniem powyższej kwestii (dotyczącej ilościowej analizy poziomu jakości linii graficznej) jest skonstruowanie funkcji $\mathrm{Q}(\mathrm{t})=\mathrm{v} \times \mathrm{C}(\mathrm{t})$ (Dziechciaruk, 2019). Funkcja ta umożliwiłaby analizę wartości iloczynu $\mathrm{v} \times \mathrm{C}$ (w trakcie kreślenia badanej linii graficznej) mierzonego w kolejnych punktach wzdłuż tej linii, odpowiadających kolejnym momentom czasowym. Ponieważ poziom jakości linii graficznej w pełni określa indywidualność pisma ręcznego, powyższa funkcja $\mathrm{Q}(\mathrm{t})$ może być również wykorzystana jako próba matematycznego i kompletnego opisu indywidualności pisma ręcznego i podpisów.

Dogłębne poznanie natury indywidualności pisma ręcznego będzie miało niewątpliwie istotne znaczenie dla jeszcze bardziej wiarygodnego i trafnego opiniowania w badaniach identyfikacyjnych pisma ręcznego i podpisów. Może również w znaczący sposób pomóc przy opracowywaniu bardziej skutecznych i precyzyjnych metod komputerowych do ekspertyzy pisma, opartych na kompleksowej, jednocześnie przeprowadzanej analizie tempa kreślenia odpowiadającego za dynamikę pisma i krzywizny odpowiadającej za kształt pisma, czyli dwóch fundamentalnych właściwości grafizmu, których wzajemne oddziaływanie kreuje indywidualność pisma ręcznego. 